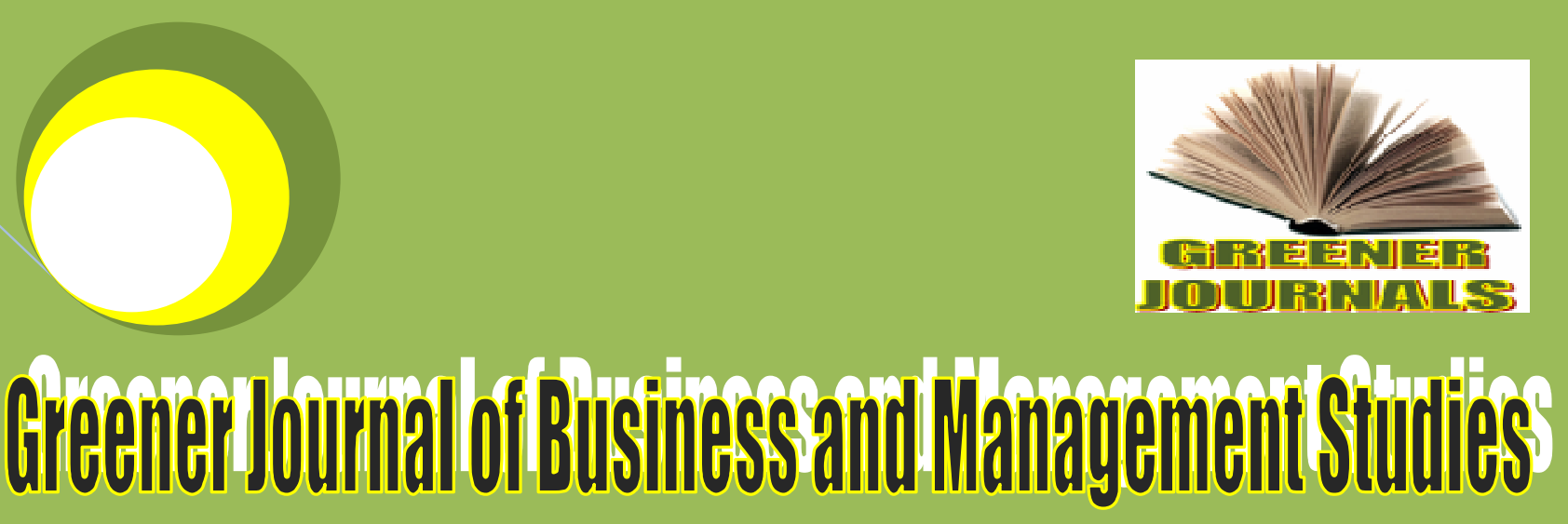

ISSN: 2276-7827 ICV: 6.02

Submitted:16/03/2016

Accepted: 22/03/2016

Published: 30/04/2016

Subject Area of Article: Marketing

DOI: http://doi.org/10.15580/GJBMS.2016.1.031616064

Evaluating Promotion Ethics in Grocery

Retailing: The View of

Harare Customers

\author{
By \\ Vutete C \\ Chikosha F
}

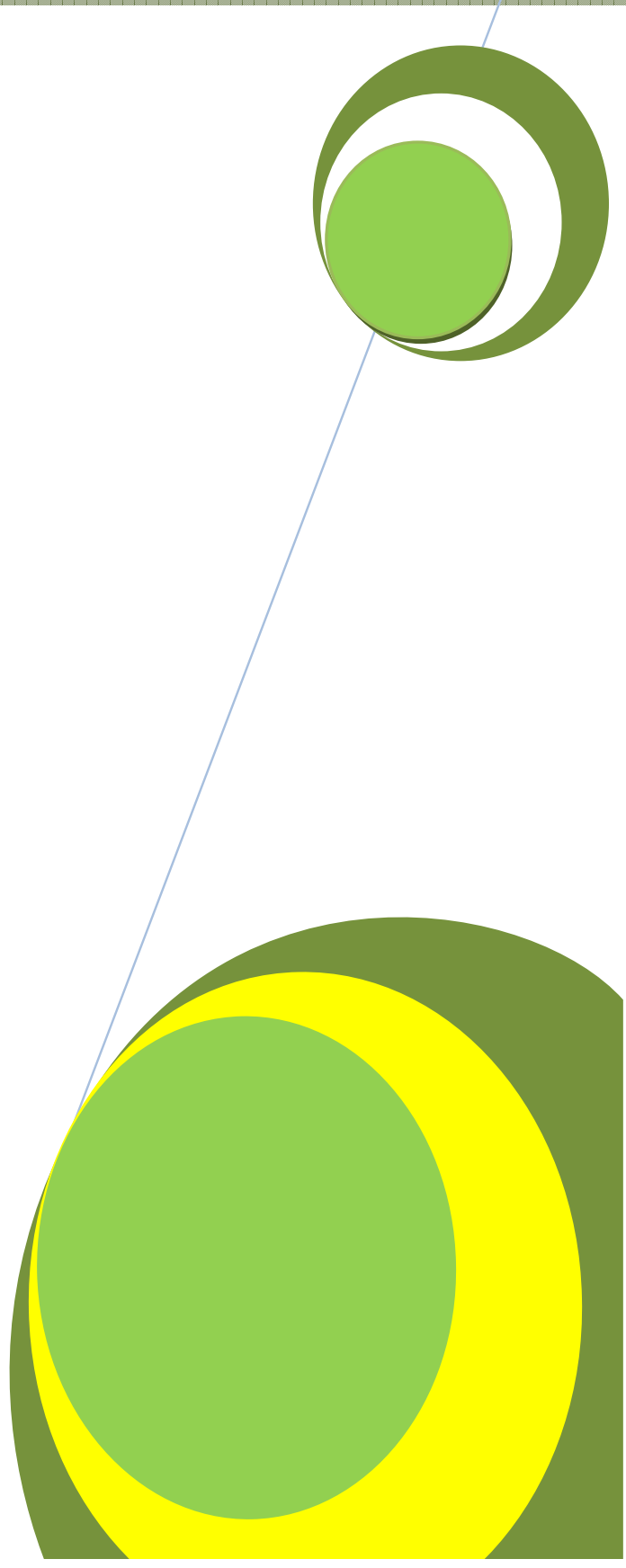




\title{
Evaluating Promotion Ethics in Grocery Retailing: TheView of Harare Customers
}

\author{
Vutete C, ${ }^{*}$ Chikosha F
}

Department of Business Management, Zimbabwe Open University, 209 Hay Road Bindura.

${ }^{*}$ Corresponding Author's Email: frixch @hotmail .com

\begin{abstract}
While grocery retailers and other businesses in the developed world are now worried about green ethics and socialresponsibility, their counterparts in Zimbabwe are facing ethical complaints around the marketing of their products. Adescriptive study conducted on whether Harare grocery retail customers were ethically satisfied by the product promotions offeredby grocery retailers was carried out with 210 customers taken from various suburbs in Harare. The sample wasestablished through quota and systematic sampling methods. Product promotion unethical practices were found to include deceptive messages, slim winning chances and encouraging customers to overspend.
\end{abstract}

Keywords: marketing ethics, product promotion, grocery retailers.

\section{INTRODUCTION}

For customers, the evaluation of ethics at retail level is pertinent because the grocery retail is the first link in the distribution chain. There are however some businesses that feel profitability is the only reason for being in business without even regard for the customer. Such businesses have been seen to disregard ethical business practices in terms of product quality, pricing and promotion. In Zimbabwe there have been reported cases of expired product being sold, unfair pricing and false claims in product promotions.

The aim of this study is to evaluate product promotion ethics in grocery retailing with a view of conscientising retailers on good business conduct.OK - Zimbabwe, TM-Pick'n Pay, Spars, Food World and Choppies are the main grocery retail outlets and will be used for this study.

\section{LITERATURE REVIEW}

\section{Marketing Ethics and Grocery Retailers}

Schiffman and Kanuk(2009) were generally aware that unethical practices do occur in every marketplace and at every level of the marketing mix, namely in the design of products, in packaging, in pricing, in advertising, and in distribution. The conceptual framework of marketing ethics can be summarised using American Marketing Association's Code of ethics given below. Research has shown that most marketers and business people use one moral philosophy at work and a completely different one outside work(Dibb et al 1997:742). Some business people believe that all activities that fight competitors and increase profits are ethical and fair. They use warfare concepts like 'guerrilla warfare", 'pre-emptive first strikes', and 'counter attacks' to justify their ruthless, careless and questionable business strategies. Marketing ethics should define competitors as rivals vying for customers and markets according to socially accepted rules, and enemies as companies seeking total conquest and even elimination of other in the industry(Dibb et al 1997). Others view marketing as a game, like football or boxing, in which ordinary rules and morality do not apply. Football has rules that lead to elimination of some teams and boxing allows some injury to players! However, since customers in marketing games and exchanges are not economically self-sufficient, they cannot choose to withdraw from the game. This means that marketing ethics must make clear what rules apply in the marketing game and that the rules developed must be appropriate to the non-voluntary participants, like customers (Kurma, 2012). 


\section{Examples of Unethical Marketing Mix Activities}

To do so requires familiarity with the many kinds of ethical issues that may arise in marketing of goods and services.

Table 1: Marketing Ethical Issues

\begin{tabular}{|l|l|}
\hline $\begin{array}{l}\text { Product issue } \\
\text { Product information }\end{array}$ & $\begin{array}{l}\text { Covering up defects in products that could cause harm to a consumer, } \\
\text { withholding critical performance information that could affect a purchase } \\
\text { decision. }\end{array}$ \\
\hline $\begin{array}{l}\text { Distribution issue } \\
\text { Counterfeiting }\end{array}$ & $\begin{array}{l}\text { Counterfeit products are widespread especially in the areas of computer } \\
\text { software, clothing and audio and video products. The internet has } \\
\text { facilitated the distribution of counterfeit products. }\end{array}$ \\
\hline $\begin{array}{l}\text { Promotion issue } \\
\text { Advertising }\end{array}$ & $\begin{array}{l}\text { Deceptive advertising or withholding of important product information in a } \\
\text { personal selling situation. }\end{array}$ \\
\hline $\begin{array}{l}\text { Pricing issue } \\
\text { Deceptive pricing }\end{array}$ & $\begin{array}{l}\text { Indicating that an advertised sale price is reduced below the regular list } \\
\text { price when in fact it is not the case. }\end{array}$ \\
\hline
\end{tabular}

Source: Adapted from Mawere M (2010) Moral Degeneration in Contemporary Zimbabwean Business Practices, Langaa Research and Publishing CIG Mankan, Bamenda

\section{Code of Marketing Managers and Grocery Retailing Ethics}

A code of ethics for marketing managers as issued by the American Marketing Association includes:

1. Basic guide lines. Not doing harm knowingly, accurate representation of their education and training, following the laws in letter and in spirit.

2. Honesty and fairness. Serving customers, clients, employees, distributors and public, avoid conflict of interest; employ equitable fee schedules and payments or receipts.

3. Principles of Rights and Duties. Follow the well understood principles of rights and duties in the process of exchange. Products should be safe, communications not deceptive in good faith, adequate processes for redress of grievances.

4. Product development. Safety standards, any component substitution to be advised to the customer, extra cost and add fake features.

5. Promotion. Avoid false, misleading, high pressure and manipulative tactics.

6. Distribution. No coercion, ensuring free channels, etc.

7. Pricing. Neither predatory nor rigged.

8. Market research. Prohibit selling under the guise of market research, research integrity, confidentiality and privacy of respondents.

9. Organisational. Avoid adverse organisational behaviour

Source: Bhatia SK (2004) Business Ethics and Corporate Governance, New Delhi, Deep and Deep Publications.

In a bid to achieve ethical marketing practice, firms are introducing the enlightened marketing philosophy, which holds that a firm's marketing activities should support the best long-run performance of the marketing system. It consist of the five principles, namely, consumer orientation marketing, innovative marketing, value marketing, sense of mission marketing and societal marketing.

\section{Promotion and Grocery Retailers Ethical Issues}

\section{Deceptive Promotion}

Promotion can create ethical issues in a variety of ways, among them false or misleading advertising and manipulative or deceptive sales promotions, tactics and publicity. A major ethical issue in promotion pertains to the marketing of video games that have been accused of promoting violence and weapons to children. Many other ethical issues are linked to promotion, including the use of bribery in personal selling situations. Even when a bribe is offered to benefit the organisation, it is usually considered unethical (Kumar, 2012). Because it jeopardises trust and fairness, it hurts the organisation in the long run. It should be noted that an informed consumer is not something that the advertising industry is trying to build(Shaw and Clarke, 1999). 


\section{Advertising Ethics and Social Responsibility}

Mass media communication, especially advertising, has been criticised internationally over a long period of time for being deceptive, manipulative, offensive, and for influencing people to buy products or services they do not need (Shimp, 2003, and De Pelsmacker 2009:38). Advertisers must assume high standards of social responsibility, particularly to groups vulnerable to persuasive statements due to their limited cognitive development (Kitchen and de Pelsmacker 2009:39).

\section{Materialism}

Advertising is also criticised for contributing to the broader issue of consumerism, creating a materialistic, consumerist mentality, which has environmentally damaging implications (Kitchen and de Pelsmacker 2009:39). Retailers are pressured by a majority of grocery retailers to sell products with direct and indirect rewards. Some of the tactics they are collaborating/or pressured to use are generally antisocial and unethical.

\section{MATERIALS AND METHODS}

A descriptive survey was used for this study. The research instrument was a questionnaire with questions on product promotion. A sample size of 210 was obtained. A Likert scale rating product promotion items was used with categories on the continuum "strongly agree" to "strongly disagree". Results were analysed using SPSS to compute means and the t- test.Reliability was almost good for the product promotion items; alpha= 0,493 as measured by Cronbach's Alpha Values. Good reliability is when Alpha is above 0, 50 . To ensure validity the questionnaire was pilot tested on customers across the selected five retail outlets.

\section{Hypothesis: There are ethical problems in the area of promotion programmes of grocery retailers}

\section{RESULTS AND DISCUSSION}

\section{Promotion and Grocery Retailers Ethical Issues}

Promotion involves use of advertising sales, promotions, personal selling, public relations, exhibitions and publicity. Each item is described basing on the ethical severity.

Table 2: Ethical Issues of Grocery Retailers on Promotion Mix

\begin{tabular}{|c|c|c|c|c|c|c|}
\hline$N=210$ & Means & $\begin{array}{l}\text { Strongly } \\
\text { Agree }\end{array}$ & Agree & $\begin{array}{l}\text { Not } \\
\text { Sure }\end{array}$ & $\begin{array}{l}\text { Dis- } \\
\text { Agree }\end{array}$ & $\begin{array}{l}\text { Strongly } \\
\text { Disagree }\end{array}$ \\
\hline $\begin{array}{l}\text { 1. Grocery retailers offers sales promotion } \\
\text { rewards only to one or few lucky customers. }\end{array}$ & 2.09 & 32.9 & 39.0 & 16.7 & 9.0 & 2.4 \\
\hline $\begin{array}{l}\text { 2. Grocery retailers give more attention to selling } \\
\text { drugs and alcohol products to children. }\end{array}$ & 3.78 & 4.8 & 6.2 & 23.3 & 37.6 & 28.1 \\
\hline $\begin{array}{l}\text { 3. Grocery retailers use naked people in their } \\
\text { adverts. }\end{array}$ & 3.78 & 5.7 & 10.0 & 15.7 & 36.7 & 31.4 \\
\hline $\begin{array}{l}\text { 4. Grocery retailers offers too many in-store sales } \\
\text { promotions to consumers that add to product } \\
\text { costs in future }\end{array}$ & 2.40 & 19.5 & 38.1 & 29.0 & 10.0 & 3.3 \\
\hline $\begin{array}{l}\text { 5. Grocery retailers offers messages that } \\
\text { encourage overspending by consumers. }\end{array}$ & 2.17 & 29.5 & 42.4 & 12.4 & 12.9 & 2.9 \\
\hline $\begin{array}{l}\text { 6. Grocery retailers use message that lie and } \\
\text { deceive customers on product availability and } \\
\text { benefits. }\end{array}$ & 2.45 & 23.8 & 36.2 & 15.7 & 19.5 & 4.8 \\
\hline
\end{tabular}

\section{Grocery Retailers Offers Sales Promotion Rewards Only to One or Few Lucky Customers.}

A mean value of 2.09 was established in the research. This shows consumers are concerned about such a strategy or provision. Retailers have a feeling that many customers should be given a chance to win the offers on sales promotions. The OK Grand Challenge was mentioned as full of ethical questions since the draw gives a very tiny probability for consumers to win. Many in-store promotions done by Food World, TM, and Spars were 
also perceived as unethical from that point. The percentage analysis showed that $71,9 \%$ agreed that this item is a big ethical issue. Only $11.4 \%$ disagreed to this statement. This might require grocery retailers to come up with more purchasing related incentives in their sales promotions (Pride and Ferrel, 2012).

\section{Grocery retailers give more attention to selling drugs and alcohol products to children.}

A mean value of 3.78 was derived in this research item. This shows many consumers disagreed with the ethical allegation levelled against grocery retailers. The shops seem to be reserved in the area of selling and displaying beer, cigarettes and wineries to customers. The percentage analysis of $65.7 \%$ supported the mean results by disagreeing to the statement. This is shown by the bar graph below.

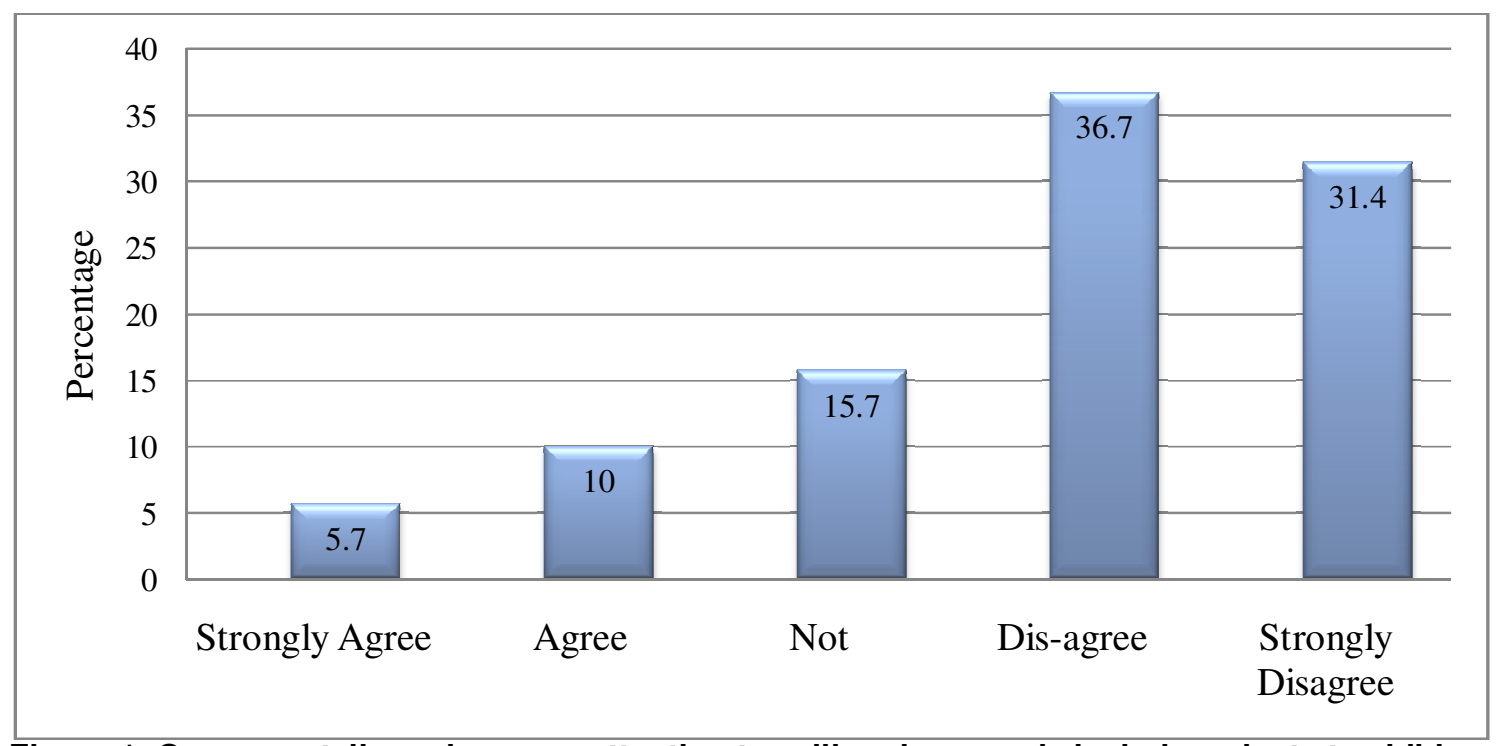

Figure 1: Grocery retailers give more attention to selling drugs and alcohol products to children

\section{Grocery retailers use naked people in their adverts.}

Jobber (2010) indicated that use of naked women and people were some unethical aspects in most adverts in both developed and developing countries. In this study a mean value of 3.78 was established. Since grocery retailers contain more of food items, there could be less temptation to use sexual appeal in their localised adverts and promotional messages. A majority of $68.1 \%$ respondents disagreed on the statement that grocery retailers in Harare use naked people in their advertising. Only $15.7 \%$ indicated that the grocery retailers use naked people in promotional messages.

\section{Grocery retailers offer too many in-store sales promotions to consumers that add to product costs in future.}

A mean value of 2.40 which is far less than 2.75 was established. The value shows that use of sales promotions is perceived as rampant by consumers. Cars, motor bikes, stands, houses, and refrigerators are the most common prizes to be won in the promotions. Customers in Harare mainly ask the question of "who pays for such expenses?" their answer is usually "The customer", they feel cheated and given an unnecessary budget. The percentage analysis confirms this to be unethical by a $57.6 \%$ overall agreement. This full range of response on this item is shown by Figure 2 below. 


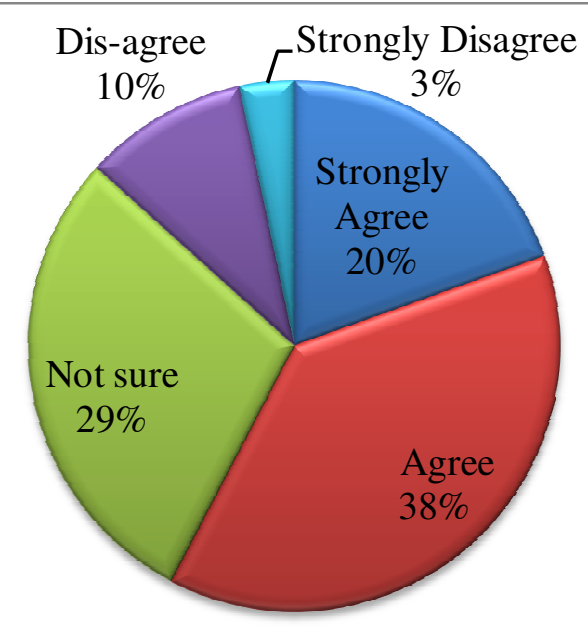

Figure 2: Grocery retailers offers too many in-store sales promotions to consumers that add to product costs in future

The figure shows that "not sure", got $29 \%$, disagree is $10 \%$ and strongly disagree shows a $3.3 \%$.

Grocery retailers offers messages that encourage overspending by consumers.

This was shown to be a serious threat in the ethical behaviour of retailers. The research established a mean of 2.17 for this item. The percentage analysis also show a $71.9 \%$ level of overall agreement that overspending message are given to grocery customers. Making people overspend and sometimes getting broke is generally unethical. Shopkeepers, in-store adverts and some in-store promotions encourage people to buy items that were not budgeted for. This was found to be annoying and harassing customers. To retailers it seems to be the best way of achieving sales quotas. This was however criticised by Kitchen and de Pelsmacker (2009) as causing unnecessary materialism and consumerist mentality.

Grocery retailers use message that lie and deceive customers on product availability and benefits.

The mean value of 2.45 in the 1-5 Likert scale indicates that respondents were more on the agreement side than on the disagreement side. Methods of deceiving and lying to customers used by grocery retailers include healthy appeal, quality appeal, durability and performances. They also say: "This is the last on stock" to induce purchasing decisions basing on shortage appeal. Products good for parents can be said to be good for children also. This can cause cognitive dissonance and dissatisfaction on the side of customers. The percentage analysis produced a $60 \%$ level of agreement, and a $24,5 \%$ level of disagreement on this ethical concern. Those not sure were $15.7 \%$.

\section{Ranking of Promotion Related Issues Starting With the Most Unethical Strategy}

Table 3: Promotion Ethical Issues Ranking

\begin{tabular}{|l|l|l|}
\hline Ethical item $(N=210)$ & Rank & Mean \\
\hline Grocery retailers offers sales promotion rewards only to one or few lucky customers. & 1 & 2.09 \\
\hline Grocery retailers offers messages that encourage overspending by consumers. & 2 & 2.17 \\
\hline $\begin{array}{l}\text { Grocery retailers use message that lie and deceive customers on product availability and } \\
\text { benefits. }\end{array}$ & 3 & 2.45 \\
\hline $\begin{array}{l}\text { Grocery retailers offers too many in-store sales promotions to consumers that add to } \\
\text { product costs in future }\end{array}$ & 4 & 2.40 \\
\hline Grocery retailers give more attention to selling drugs and alcohol products to children. & 5 & 3.78 \\
\hline Grocery retailers use naked people in their adverts. & 6 & 3.78 \\
\hline
\end{tabular}




\section{Hypothesis testing and Promotional Ethics}

Table 4: t-Test: Paired Two Sample for Means

\begin{tabular}{|l|l|l|}
\hline & Variable 1 & $\begin{array}{l}\text { Variable } \\
\mathbf{2}\end{array}$ \\
\hline Mean & 2.84456 & 2.5 \\
\hline Variance & 0.746114593 & 0 \\
\hline Observations & 6 & 6 \\
\hline t Stat & 0.891963522 & \\
\hline $\mathbf{P}(\mathbf{T}<\mathbf{t})$ one-tail & 0.21141048 & \\
\hline t Critical one-tail & 2.131846782 & \\
\hline
\end{tabular}

Hypothesis: There are ethical problems in promotion strategy of grocery retailers in Harare.

$\mathrm{H}_{0}$ : mean $\leq 2.50$

$\mathrm{H}_{\mathrm{a}}$ : mean $>2.50$

We carried out a one tailed t-distribution test at $5 \%$ significance level and set to reject $\mathrm{H}_{0}$ if $\mathrm{T}_{\text {cal }}>\mathrm{T}_{\text {crit }}$

This is shown by the t-distribution test diagram below.

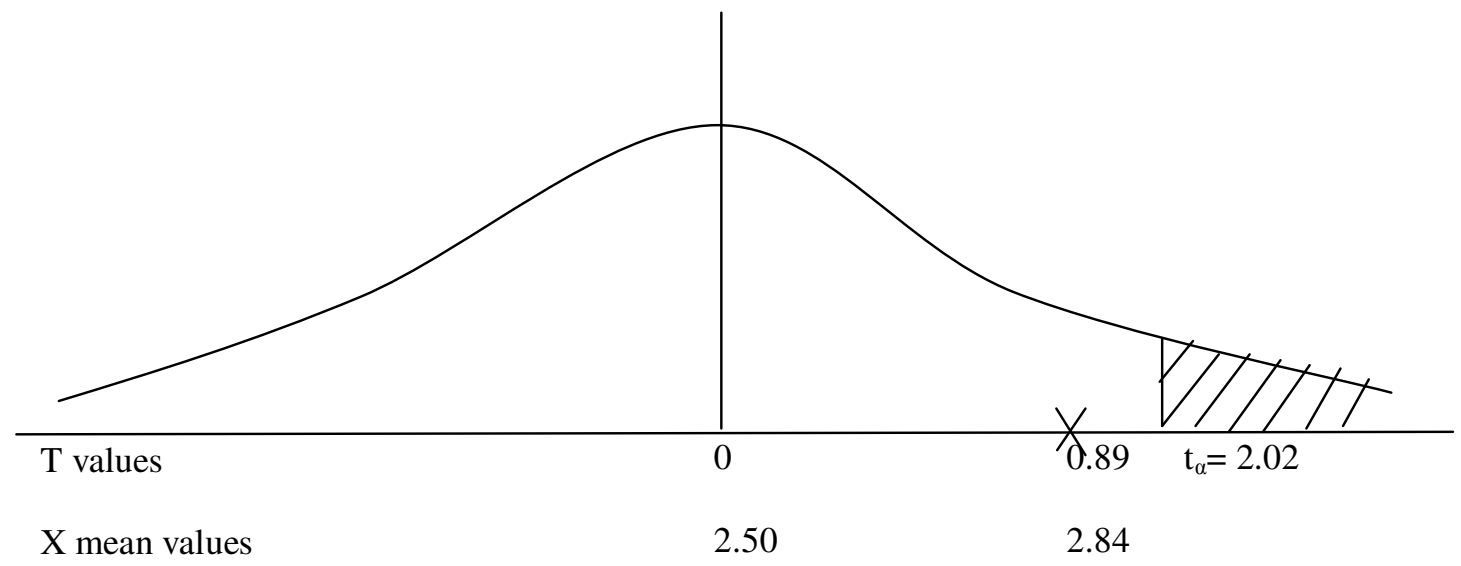

Figure 3: Promotion Hypothesis Testing

Since $t_{\text {cal }}$ value of 0.89 is less than 2.02 , we conclude that retailers are generally unethical in their promotional strategies at $5 \%$ level of significance. This shows the need of reviewing all promotional activities to make them ethical in the eyes of customers.

\section{CONCLUSION}

In promotion strategies, the ethical challenges established by the research were use of promotion rewards directed to few lucky customers, and using messages that lie and deceive customers on product availability and benefits. Retail customers face unethical communications through low chances of winning in the sales promotions, high costs promotions, messages encouraging overspending and lying on product benefits and availability. Retail customers are generally sceptical about such promotions. Promotions by retailers are likely to be used to cheat customers.

\section{COMPETING INTERESTS}

There were no competing interests foreseen in this study 


\section{AUTHORS' CONTRIBUTIONS}

The corresponding author mooted the idea and from there worked together with the co-author.

\section{ACKNOWLEDGEMENTS}

We would like to thank personnel from the Consumer council of Zimbabwe and management of the following grocery retail shops-OK - Zimbabwe, TM-Pick'n Pay, Spars, Food World and Choppies supermarkets.

\section{REFERENCES}

Bhatia S. K., (2004). Business Ethics and Corporate Governance, Deep and Deep Publications, New Delhi, India. Dibb S., Simkin L., William M. P., and Ferrell O. C., (1997). Marketing Concepts and Strategies, $13^{\text {th }}$ Edition, Boston: Haughton Miffin Company, page 742

Kitchen and de Pelsmacker (2009). "Consumer preferences for the marketing of ethically labelled coffee", International Marketing Review, Vol. 22, pp. 512-30.

Kumar S. (2012). Marketing and Business Ethics Random Publications, New Delhi, India pp184-210

Pride, W.M and Ferrel, O.C (2012). Marketing. $16^{\text {th }}$ Ed.United Kingdom

Schiffman, L.G. \&Kanuk, L.L. (2009). Consumer behaviour. $9^{\text {th }}$ Ed. Upper Saddle River: Prentice Hall.

Shaw D. and Clarke I., (1999). Belief formation in ethical consumer groups: an exploratory study Deirdre, Marketing Intelligence \& Planning 17/2 pp. 109-119

Shaw D. and Shiu E. (2003). Ethics in consumer choice: a multivariate modelling approach, European Journal of Marketing Vol. 37 No. 10, pp. 1485-1498

Shimp T. A. (2003). "Consumer Ethnocentrism: Construction and Validation of the Cetscale," Journal of Marketing Research 24

Cite this Article: Vutete C, Chikosha F (2016). Evaluating Promotion Ethics in Grocery Retailing: The View of Harare Customers. Greener Journal of Business and Management Studies, 6(1): 028-034, http://doi.org/10.15580/GJBMS.2016.1.031616064 